\title{
Democracy in the European Union: What has the Court of Justice to Say?
}

\author{
Christopher Vajda*
}

\begin{abstract}
This article examines how the core European Union Treaties and the Court of Justice of the European Union have sought to give effect to the principle of democracy within the European Union legal order. It explains that the complexity of the legislative procedure, with its checks and balances between the relevant European Union institutions, is a reflection of the need to ensure effective participation by all of them. The three main institutions of the European Union, namely the Parliament, the Council, and the Commission, represent different legitimate interests which do not always coincide. The fact that European Union legislation is multilingual and often expressed in broad terms presents its own particular challenges to the Court of Justice of the European Union when it is asked to interpret that legislation. For its part, the Court of Justice of the European Union is sensitive to the wishes of the legislature, and therefore has been willing to modify previous case law based solely on the Treaties where the legislature has subsequently signalled its intention to apply the relevant Treaty provisions in a different manner.
\end{abstract}

\section{Keywords}

Democracy, European Union, Court of Justice of the European Union

\section{Introduction}

A commitment to democracy lies at the heart of the European Union (EU). Article 10 of the Treaty on European Union (TEU) reads as follows:

1. The functioning of the Union shall be founded on representative democracy.

2. Citizens are directly represented at Union level in the European Parliament. Member states are represented in the European Council by their Heads of State or Government and in the Council by their governments, themselves democratically accountable either to their national parliaments, or to their citizens. ${ }^{1}$

* Judge of the Court of Justice of the European Union. This is a slightly fuller version of a Keynote Address given at the Cambridge Journal of International and Comparative Law Fourth Annual Conference, 'Developing Democracy: Conversations on Democratic Governance in International, European and Comparative Law, on Saturday 9 May 2015. I would like to thank Charlotte Alport who assisted me greatly in preparing both my talk and this article.

1 Consolidated Version of the Treaty on European Union [2012] OJ C326/15. 
I shall begin by briefly discussing various models of democratic states, and will then focus on the institutions that comprise the Union and their respective roles in the legislative process at the EU level. I will then turn to an analysis of how the Court of Justice of the European Union (CJEU) ${ }^{2}$ interprets EU legislation, before, lastly, looking briefly at the application of the Charter of Fundamental Rights ${ }^{3}$ to EU legislation.

\section{The various models of democratic states}

\subsection{Nation states}

In a unitary state, the basic principle is that a democratically elected legislature adopts primary legislation. In the United Kingdom (UK), many Acts of Parliament provide, however, for the executive to adopt what is termed delegated or secondary legislation. Where a state has a written constitution, such as in Germany or the United States, the legislature has to act within the confines of the constitution, which is the supreme law of that state. Adapting to the supremacy of what is now EU law has caused difficulties for some Member States whose constitutions are supreme. For example, for Germany, such difficulties arose as a result of a potential conflict between its domestic human rights protection, enshrined in its Basic Law, and the perceived absence of such protection under EU law. ${ }^{4}$

\subsection{The EU}

In a regional supranational organisation, such as the Council of Europe or the EU, the participating states agree to pool part of their sovereignty. This pooling or limitation has to be agreed by the national legislature. The EU is a very particular supranational organisation as it has its own legislative capacity.

It is clear that the EU, made up of 28 Member States, has a plethora of competing interests to consider, and, in order to function successfully, requires a complex and unique system of checks and balances. This is achieved, in part, through the upholding of

2 Prior to the entry into force of the Treaty of Lisbon amending the Treaty on European Union and the Treaty establishing the European Community [2007] OJ C306/01 (Treaty of Lisbon), the CJEU was known as the European Court of Justice but in this article I will refer to the CJEU also in respect of judgments delivered before 1 December 2009.

3 Charter of Fundamental Rights of the European Union [2012] OJ C326/391.

4 Case C-29/69 Stauder v Stadt Ulm [1969] ECR 419; Case C-11/70 Internationale Handelsgesellschaft GmbH v Einfuhr-und Vorratsstelle für Getreide und Futtermittel [1970] ECR 1125; Case C-4/73 Nold KG $v$ Commission [1974] ECR 491. See also Internationale Handelsgesellschaft $v$ Einfuhr und Vorratsstelle für Getreide und Futtermittel [1974] 2 CMLR 540 (Solange I); Wünsche Handelsgesellschaft [1987] 3 CMLR 225 (Solange II). 
institutional balance between the main institutions, namely, the Council, the Parliament and the Commission, as set out in article 13(2) TEU:

Each institution shall act within the limits of the powers conferred upon it in the Treaties, and in conformity with the procedures, conditions and objectives set out in them.

This ensures that a careful weighting of institutional power is achieved in order to safeguard both national and Union interests. Within this institutional structure, each body represents the different interests which make up the Union:

1. It is the European Parliament which, through being directly elected by EU citizens, represents directly the citizens in the legislative process.

2. The Council represents the interests of the individual Member States, whose governments have all been democratically elected.

3. It is the Commission that has been given the role of initiator of the legislative process and is the guardian of the Treaties.

\section{The EU legislative process}

The delicate balancing act between these three institutions is illustrated by the Union's legislative procedures, which show the extent of each body's input and the voting requirements put in place by the Treaties in order to regulate the process.

There is no single EU institution that is prescribed sole responsibility for the adoption of legislation-the Commission, Council and Parliament share this duty, and carry out the various roles prescribed to them in the Treaties. There are two legislative processes, the ordinary legislative procedure ${ }^{5}$ and the special legislative procedure. ${ }^{6}$ The ordinary legislative procedure applies to the vast bulk of the legislation adopted by the EU.

\subsection{The ordinary legislative procedure}

The procedure consists of a number of different stages, which vary depending on the point at which agreement, in the manner set out in the Treaties, is reached. The process often involves three stages, comprising a first and second reading, and the establishment of a subsequent conciliation committee if no agreement is reached.

The Commission submits its proposal to the Parliament and Council for what is termed a first reading. It is the Commission, therefore, that sets the framework for the entire legislative process, subject to three caveats. The first two have a legal basis: article 2 of Protocol 2 requires the Commission to consult widely before making

5 Consolidated Version of the Treaty on the Functioning of the European Union [2012] OJ C326/47 (TFEU) art 294.

6 Art 289(2) TFEU. 
legislative proposals; ${ }^{7}$ also the European Citizens Initiative gives EU citizens, under certain conditions, the opportunity to invite the Commission to bring forward an appropriate proposal (which includes legislation). ${ }^{8}$ Finally, from a practical perspective, the Commission has to be alert to the wishes of the Council and European Parliament.

The Council and Parliament have equal power within the decision-making process; however, put briefly, the Council and Parliament are not entitled to depart from the parameters set by the Commission's proposal. In Eurotunnel $v$ SeaFrance, ${ }^{9}$ Eurotunnel challenged the validity of an article in a Council Directive which gave a temporary reprieve to pre-existing duty free arrangements within the European Community (EC). The Commission's proposal, in the context of the single market, which came into force on 1 January 1993, abolished such arrangements from that date. The Council added a number of provisions ${ }^{10}$ at the final stage of the legislative process, maintaining in force the exemption conditions for intra-Community trade involving air and sea travellers, for a limited period. The CJEU ruled that, as long as the Council's amendments did not stray beyond the scope of the Commission's original proposal, the Council did not exceed its power to amend. ${ }^{11}$

If the Commission does not agree with the amendments made by the Council and Parliament it may amend ${ }^{12}$ or withdraw its proposal until the start of the conciliation process. Very recently, the CJEU had to decide the circumstances in which the Commission can withdraw its proposal. ${ }^{13}$ The Commission made a proposal, initiating the ordinary legislative procedure, for a framework regulation, which laid down general provisions for the dispersal of aid to third countries. The Commission stated in the recitals to the proposal that such a framework regulation would avoid the unnecessary delays engendered when aid decisions were made on an ad hoc basis via the ordinary legislative procedure. The Parliament and Council expressed concerns that such a regulation would lead to insufficient political and democratic scrutiny and so decided

7 Protocol (No 2) on the Application of the Principles of Subsidiarity and Proportionality [2012] OJ C326/206, art 2.

8 Art 11(4) Treaty of Lisbon, and see further below.

9 Case C-408/95 Eurotunnel and Others $v$ SeaFrance [1997] ECR I-6315. Although the legislative procedure was different at that time, the Council was still bound to remain within the parameters of the Commission's proposal. See art 189a(1) Treaty of Lisbon: 'Where, in pursuance of this Treaty, the Council acts on a proposal from the Commission, unanimity shall be required for an act constituting an amendment to that proposal, subject to Article $189 \mathrm{~b}(4)$ and (5).'

10 Council Directive 77/388/EEC of 17 May 1977 on the harmonisation of the laws of the Member States relating to turnover taxes-Common system of value-added tax: uniform basis of assessment [1977] OJ L145/1, art 28k, as inserted by Council Directive 91/680/EEC of 16 December 1991 supplementing the common system of value added tax and amending Directive 77/388/EEC with a view to the abolition of fiscal frontiers [1991] OJ L376/1, art 1(22); Council Directive 92/12/EEC of 25 February 1992 on the general arrangements for products subject to excise duty and on the holding, movement and monitoring of such products [1992] OJ L76/1, art 28.

11 Case C-408/95 Eurotunnel $v$ SeaFrance (n 9) paras 33-62.

12 Art 293(2) TFEU: 'As long as the Council has not acted, the Commission may alter its proposal at any time during the procedures leading to the adoption of a Union act.'

13 Case C-409/13 Council v Commission [2015] EU:C:2015:217. 
that they intended to retain the use of the ordinary legislative procedure as the process for making such decisions. The Commission withdrew its proposal, on the grounds that such an amendment would distort its original proposal and deprive it of its raison dêtre. The Council brought an action before the CJEU for the annulment of the Commission's decision. The Council argued that the Commission exceeded the powers conferred upon it in the Treaties and, as such, undermined the principle of institutional balance and infringed the principle of sincere cooperation, and acted contrary to the democratic principles of the Union. ${ }^{14}$ The judgment found in favour of the Commission. ${ }^{15}$ The CJEU stated that, in making a proposal, the Commission's role is to promote the general interest of the EU. ${ }^{16}$ This comes with two safeguards attached:

1. the Council alone can amend the proposals put forward by the Commission only if it acts unanimously; and

2. the Commission may alter its proposal at any time during the procedure leading to the adoption of an act, as long as the Council has not yet acted. ${ }^{17}$

The CJEU found that the amendments put forward by the Parliament and the Council would have distorted an essential element of the proposal for a framework regulation in a manner irreconcilable with the objective pursued by the proposal of improving the effectiveness of EU policy in this area. ${ }^{18}$ The CJEU held that the Commission's power to withdraw the proposal is inseparable from its right to initiate the legislative procedure which derives from the Treaties. ${ }^{19}$ This case illustrates that the principle of democracy cannot be regarded in isolation from other EU principles, including that of institutional balance.

If, after the completion of the first and second readings, no agreement is reached, the Presidents of the Council and the Parliament have six weeks in which to form a conciliation committee, consisting of an equal number of Council and Parliament members. In Elfaa, ${ }^{20}$ the CJEU identified the very nature of the term 'conciliation' as

\footnotetext{
14 ibid paras $32-50$.

15 ibid paras $108-09$.

16 ibid para 70.

17 ibid para $71-73$.

18 ibid para 91.

19 ibid para 96:
}

As to the line of argument alleging an infringement of the principle of democracy laid down in art 10(1) and (2) TEU, it is apparent from art 17(2) TEU, read in conjunction with arts 289 TFEU and 293 TFEU, that the Commission has the power not only to submit a legislative proposal but also, provided that the Council has not yet acted, to alter its proposal or even, if need be, withdraw it. Since that power of the Commission to withdraw a proposal is inseparable from the right of initiative with which that institution is vested and its exercise is circumscribed by the provisions of the abovementioned articles of the FEU Treaty, there can be no question, in this instance, of an infringement of that principle. Accordingly, this line of argument must be rejected as unfounded. 
conferring a wide discretion. ${ }^{21}$ The CJEU also highlighted that the committee's main purpose is to reach agreement on a joint text, taking into account the Parliament's proposed amendments and the position adopted by the Council. The committee would not, for example, exceed its powers by adopting an amended article when no amendment had been made to that article by the Parliament at the second reading. ${ }^{22}$ During this process, the Commission, which no longer has the right to withdraw its proposal, takes on the role of mediator between the Council and Parliament.

Unless stated otherwise in the Treaties, the Council shall act by qualified majority. ${ }^{23}$ This is also the case throughout the ordinary legislative process. The Council, comprising 28 members, one from each Member State, therefore makes a series of compromises during the adoption of legislation. However, some exceptions exist to this voting system. For example, if at the second reading, the Commission returns a negative opinion on the Parliament's amendments, the Council has the power to adopt the amended proposal if it returns a unanimous vote. ${ }^{24}$

\subsection{The special legislative procedure}

The special legislative procedures apply to a smaller number of areas of Union law-making than the ordinary legislative procedure. However, many of these areas have far-reaching implications covering areas such as taxation, passport provisions and accession of new Member States. ${ }^{25}$ The process is entirely different in terms of the level of participation allowed to the Parliament. The Parliament is either consulted on or is required to give its consent to the Council's decisions, so does not take the role of co-legislator as it does in the ordinary legislative procedure.

Where Parliament's consultation is required, the Council is under a duty to request an opinion from the Parliament, allowing it a reasonable period of time to provide its opinion. However, there is no requirement for the Council to account for the impact of the Parliament's opinion in the legislation adopted. In Isoglucose, it was stated that, although the Parliament's role is limited, 'it reflects at Community level the fundamental democratic principle that the peoples should take part in the exercise of power. ${ }^{26}$ Consultation of the Parliament is required, for example, under article 77(3) TFEU with regards to provisions for passports, identity cards and residents' permits. ${ }^{27}$

21 ibid para 58.

22 ibid para 59.

23 Art 16(3) TEU.

24 Art 294(9) TFEU.

25 Arts 113, 77(3), 218 TFEU.

26 Case C-138/79 Roquette Frères v Council [1980] ECR 3333, para 33.

27 Art 77(3) TFEU:

If action by the Union should prove necessary to facilitate the exercise of the right referred to in Article 20(2)(a), and if the Treaties have not provided the necessary powers, the Council, acting in accordance with a special legislative procedure, may adopt provisions concerning passports, identity cards, 
Sometimes the consent of the Parliament is required by the Treaties. Dialogue between the Parliament and Council is limited relative to the ordinary legislative procedure. However, the consent of the two institutions is still required for an act to be adopted. Parliamentary consent is required, for example, when a new Member State accedes to the Union. ${ }^{28}$

\subsection{Differences at the EU and national levels}

This system of checks and balances obviously differs in many ways from the procedures at the national level. First, it is the Commission that has a virtual monopoly on initiating legislation, rather than, at national level, the executive or indeed the democratically accountable legislator. ${ }^{29}$ Secondly, the Parliament and Council have equal weight in the ordinary legislative process, taking a shared role in proposing and reconciling amendments to Commission proposals. Finally, a considerable degree of compromise is required on the part of Member States and their individual citizens, who must embrace the 'give-and-take' nature of EU decision-making procedures. Each Member State is just one of 28 , so compromise must occur within the Council. The Treaties prescribe qualified majority voting as the normal procedure for Council decisionmaking. However, exceptions exist which require unanimity from the Council in areas of particular importance, such as taxation. ${ }^{30}$ As we have also seen, further compromise may be required during the legislative process between the Parliament and Council.

Although the process is cumbersome and requires compromise it cannot be described as undemocratic. It is, rather, a very different form of democracy than that which exists within the Member States. One of the main criticisms of the EU legislative process is that the role of national parliaments has been seriously undermined. An attempt to address this criticism has been made in the TEU.

\subsection{The role of national parliaments: Subsidiarity}

The principle of subsidiarity guards against the Union acting, unless the objectives of the proposed action cannot be sufficiently achieved at the Member State level, ensuring that decision-making is entrusted to each individual Member State as far as possible, and that, therefore, any decision embodies the national identity and democratic will of that state.

residence permits or any other such document. The Council shall act unanimously after consulting the European Parliament.

28 Art 49 TEU: 'The applicant State shall address its application to the Council, which shall act unanimously after consulting the Commission and after receiving the consent of the European Parliament, which shall act by a majority of its component members.'

29 See Case C-409/13 Council v Commission (n 13).

30 Art 113 TFEU. 
To reinforce the observance of the principle, article 12(b) TEU states that national parliaments contribute actively to the good functioning of the Union: by seeing to it that the principle of subsidiarity is respected. The principle of subsidiarity, as described in article 5(1)-(4) TEU, is to ensure that decisions are taken as closely as possible to the citizens of the EU. ${ }^{31}$

National parliaments, within eight weeks of the transmission of a draft legislative act, have the right to object to the act on the grounds that it does not comply with the principle of subsidiarity. This is achieved by submitting an opinion, with reasons, to the European Parliament, the Council and the Commission. However, this does not automatically lead to the opinion being taken into account. Each national parliament has two votes. An objection of one-third of all of the votes allocated to the national parliaments is required before what is called the 'yellow card procedure' is activated. ${ }^{32}$

However, the procedure is relatively limited in scope, in that, when activated, the Commission must review the draft proposal in light of the opinion put forward, but is under no obligation to amend or withdraw the proposal. It must, however, offer reasons for its decision. The 'orange card procedure ${ }^{33}$ goes one step further, in that, during the ordinary legislative procedure, if the majority of national parliaments object, the Commission must not only review its proposal, but also provide a written explanation of how the subsidiarity principle is complied with should it wish to maintain the proposal.

31 In Case C-58/08 Vodafone and Others [2010] ECR I-4999, the CJEU ruled that if two interdependent issues were at stake, one which could be dealt with at national level, the other a matter for the Union, both issues should be dealt with at the Union level in order to secure the smooth functioning of the Union, by providing a single coherent regulatory framework. The intervention by the Community legislature in such a case is not a breach of the principle of subsidiarity.

32 Arts 6, 7 Protocol (No 2) on the Application of the Principles of Subsidiarity and Proportionality. Art 7 provides:

1. The European Parliament, the Council and the Commission, and, where appropriate, the group of Member States, the Court of Justice, the European Central Bank or the European Investment Bank, if the draft legislative act originates from them, shall take account of the reasoned opinions issued by national Parliaments or by a chamber of a national Parliament.

Each national Parliament shall have two votes, shared out on the basis of the national Parliamentary system. In the case of a bicameral Parliamentary system, each of the two chambers shall have one vote.

2. Where reasoned opinions on a draft legislative act's non-compliance with the principle of subsidiarity represent at least one third of all the votes allocated to the national Parliaments in accordance with the second subparagraph of paragraph 1 , the draft must be reviewed. This threshold shall be a quarter in the case of a draft legislative act submitted on the basis of Article 76 of the Treaty on the Functioning of the European Union on the area of freedom, security and justice.

After such review, the Commission or, where appropriate, the group of member states, the European Parliament, the Court of Justice, the European Central Bank or the European Investment Bank, if the draft legislative act originates from them, may decide to maintain, amend or withdraw the draft. Reasons must be given for this decision.

33 ibid art 7(3). 


\subsection{European Citizens' Initiative (ECI)}

The introduction of the $\mathrm{ECI}^{34}$ allows $\mathrm{EU}$ citizens to participate directly in the development of EU policies by inviting the European Commission to propose legislation where the EU has competence to legislate. The initiative must be backed by at least one million EU citizens, coming from at least seven of the 28 Member States, with further requirements that a certain number of those signatories come from each of the Member States. However, the Commission has no obligation to take any action. Since the coming into force of implementing legislation in April 2012, ${ }^{35}$ three petitions have fulfilled the requirements set out in the Regulations, although 20 different initiatives have been launched and have been submitted to the Commission. The first entitled 'Water and Sanitation are a human right! Water is a public good, not a commodity!' received a positive response in March 2014. ${ }^{36}$ The Commission identified gaps and areas where more can be done at both EU and national level in existing EU water legislation. The

34 Art 11(4) TEU:

Not less than one million citizens who are nationals of a significant number of Member States may take the initiative of inviting the European Commission, within the framework of its powers, to submit any appropriate proposal on matters where citizens consider that a legal act of the Union is required for the purpose of implementing Treaties.

35 Regulation (EU) No 211/2011 of the European Parliament and of the Council of 16 February 2011 on the citizens' initiative [2011] OJ L65/1; Commission Implementing Regulation (EU) No 1179/2011 of 17 November 2011 laying down technical specifications for online collection systems pursuant to Regulation (EU) No 211/2011 of the European Parliament and of the Council on the citizens' initiative [2011] OJ L301/3.

36 Communication from the European Commission on the European Citizens' Initiative 'Water and sanitation are a human right! Water is a public good, not a commodity!' of 19 March 2014 COM (2014) 177 Final 13:

In response to the citizens' call for action, the Commission is committed to take concrete steps and work on a number of new actions in areas that are of direct relevance to the initiative and its goals. In particular, the Commission:

- will reinforce implementation of its water quality legislation, building on the commitments presented in the 7th EAP and the Water Blueprint;

- will launch an EU-wide public consultation on the Drinking Water Directive, notably in view of improving access to quality water in the EU;

- will improve transparency for urban wastewater and drinking water data management and explore the idea of benchmarking water quality;

- will bring about a more structured dialogue between stakeholders on transparency in the water sector;

- will cooperate with existing initiatives to provide a wider set of benchmarks for water services;

- will stimulate innovative approaches for development assistance (eg support to partnerships between water operators and to public-public partnerships); promote sharing of best practices between Member States (eg on solidarity instruments) and identify new opportunities for cooperation.

- will advocate universal access to safe drinking water and sanitation as a priority area for future Sustainable Development Goals.

Finally, the Commission invites the member states, acting within their competences, to take account of the concerns raised by citizens through this initiative and encourages them to step up their own efforts to guarantee the provision of safe, clean and affordable drinking water and sanitation to all. 
second, against financing activities presupposing embryo destruction, ${ }^{37}$ was rejected, and the third recently received a reply. ${ }^{38}$

\subsection{Role of the CJEU}

The arbiters and enforcers of this complex set of rules are the EU courts. All three main institutions are not shy in coming to the CJEU to enforce what they consider to be their legislative prerogatives. Thus, the European Parliament has exercised this right in 142 cases in the last five years before either the CJEU or the General Court.

\section{Interpretation of legislation}

The role of a court in interpreting any legislation is to give effect to the will of the legislator. At the Union level, problems arise in the interpretation of legislation which are not present at the national level.

\subsection{Language}

Unlike the UK, the EU has 24 official languages. The problems that arise from this are well illustrated in the EMU Tabac case, ${ }^{39}$ on the interpretation of a customs directive. EMU Tabac raised the point in proceedings before the CJEU that the French, Italian, Spanish, German, Dutch and Portuguese versions of the relevant directive did not preclude the use of an agent in order to benefit from the rate of duty in the Member States from which the goods were dispatched which, in that case, was lower than the duty applicable in the member state of destination. By contrast, the Danish and Greek versions clearly indicated that for excise duty to be payable in the country of dispatch, transportation must be effected personally by the purchaser of the products subject to duty. EMU Tabac argued that, in so far as they were inconsistent with other versions, the Danish and Greek versions ought to be disregarded, especially given the fact that, at the time the Directive was adopted, those two Member States represented in total only 5 per cent of the population of the then 12 Member States, and their languages were not easily understood by the nationals of the 10 other Member States. ${ }^{40}$ It is not surprising that the CJEU firmly rejected this approach. In its view, to discount two language versions, as the applicants in the main proceedings were suggesting, would run counter to the CJEU's

37 Communication from the European Commission on the European Citizens' Initiative 'One of us' of 28 May 2014 COM (2014) 355 Final.

38 Communication from the European Commission on the European Citizens' Initiative 'Stop Vivisection' of 3 June 2015 COM (2015) 3773 Final.

39 Case C-296/95 The Queen v Commissioners of Customs and Excise, ex parte EMU Tabac and others [1998] ECR I-1605.

40 ibid para 34. 
settled case law that, in the interests of a uniform interpretation of EU law, the text of a provision must be interpreted and applied in the light of the versions existing in the other official languages, and not in isolation. ${ }^{41}$

\subsection{Recitals and other aids to interpretation}

Legislation of the UK is generally drafted in a much more detailed way than EU legislation. This means there are fewer 'gaps' to be filled by the courts. When UK legislation is truly ambiguous, the courts can seek guidance, albeit under very strict conditions, from parliamentary statements concerning the purpose of legislation in order to interpret ambiguous statutory provisions in line with the decision in Pepper $v$ Hart. $^{42}$

At the EU level, the legislative procedure is complex, as we have seen. The CJEU generally restricts itself to relying on the recitals contained within a piece of legislation to determine its purpose. There are real difficulties in looking back to the various steps in the legislative process as it is complex and involves three main players. Nevertheless, the CJEU can refer to the travaux préparatoires, principally to support an interpretation of the legislation as adopted. ${ }^{43}$

Although the recitals are available to assist the CJEU, a warning was issued by Lord Mance in the HS2 case of the over-expansive interpretation of Union legislation. He stated that ' $[\mathrm{w}]$ here the legislature has agreed a clearly expressed measure, reflecting the legislators' choices and compromises in order to achieve agreement, it is not for courts to rewrite the legislation, to extend or "improve" it in respects which the legislator clearly did not intend. ${ }^{44}$ Lord Mance included among the issues that can arise from an over-zealous purposive approach to interpretation the following: first, the 'risk of loss of confidence' in EU law at the national level; second, the risk of national courts struggling to determine whether 'a point of EU law is acte clair or not', leading to a noticeable increase in the CJEU's caseload; and, finally, it becoming increasingly difficult for agreement to be reached on the adoption of EU legislation. ${ }^{45}$

41 ibid para 36. See, in particular, Case C-9/79 Koschniske v Raad van Arbeid [1979] ECR 2717, para 6.

42 Pepper (Inspector of Taxes) v Hart [1992] UKHL 3, [1993] AC 593, as qualified by Williams v Central Bank of Nigeria [2014] UKSC 10, [2014] 1 AC 1189 [104] (Lord Sumption); R (Brown) v Secretary of State for the Home Department [2015] UKSC 8, [2015] 1 WLR 1060 [27] (Lord Toulson).

43 Case C-480/08 Maria Teixeira $v$ London Borough of Lambeth and Secretary of State for the Home Department [2010] ECR I-1107, para 58. However, for an earlier case where the Court appeared to place greater reliance still on the travaux préparatoires, see Case C-402/03 Skov and Bilka [2006] ECR I-199, para 27.

$44 R$ (on the application of HS2 Action Alliance Limited) $v$ Secretary of State for Transport and another [2014] UKSC 3, [2014] 1 WLR 324 [171] (Lords Neuberger and Mance).

45 ibid [172]-[174] (Lords Neuberger and Mance). 


\subsection{The role of the Treaties}

Very often the CJEU has no legislation at all to interpret, but is asked to interpret Treaty articles. Many of the major judgments of the CJEU involve interpretation of Treaty articles. Perhaps the most celebrated example is the recognition of direct effect in Van Gend en Loos in $1963 .{ }^{46}$ When the legislator legislates, it is not bound absolutely by the CJEU's case law on a Treaty article. First, where there has been complete harmonisation by the legislator, the CJEU will look to the harmonised measure, and not to the Treaty. ${ }^{47}$ Secondly, where there is legislation, the CJEU may reconsider its previous approach under the Treaty. I will mention two examples relating to the Free Movement of Citizens Directive (Directive 2004/38). ${ }^{48}$

Bidar $^{49}$ concerned a French national, Dany Bidar, who completed his secondary education in the UK. He applied for a maintenance loan for a UK university course. The loan was refused on the basis that Mr Bidar was not 'settled' in the UK. At the time, in order to be 'settled' a person had to have lived in the UK for four years other than for the purposes of receiving full-time education. Mr Bidar did not meet that requirement. Mr Bidar challenged the decision on the grounds that it was discriminatory, and thus prohibited under article 12 of the then European Communities Treaty (EC). ${ }^{50}$

The CJEU first held that assistance to cover maintenance costs, whether in the form of subsidised loans or grants provided to students lawfully resident in the host Member State, fell within the scope of the application of the Treaty on the basis of article 18 EC (citizenship rights). This meant that the prohibition on discrimination set out in article $12 \mathrm{EC}$ was engaged. The CJEU accepted the argument that a Member State was entitled to limit such assistance to those students who demonstrated a certain degree of integration into the host Member State. The CJEU accepted that three years of residency would be permissible, so the settlement rules went too far.

This case was reconsidered in Förster, ${ }^{51}$ three years later. The Centrale Raad van Beroep, which had to rule on appeal on the action brought by Ms Förster, made an order for reference to the CJEU, requesting it to state under what conditions a student from

46 Case C-26/62 NV Algemene Transporten Expeditie Onderneming van Gend en Loos $v$ Nederlandse Administratie der Berlingen [1963] ECR 1.

47 See, for example, Case C-593/13 Rina Services [2015] EU:C:2015:399, Opinion of AG Cruz Villalón, footnote 7: 'It should be recalled that, according to settled case-law, where a sphere has been the subject of exhaustive harmonisation at EU level, any national measure relating thereto must be assessed in the light of the provisions of that harmonising measure and not of those of primary law.

48 Directive 2004/38/EC of the European Parliament and of the Council of 29 April 2004 on the right of citizens of the Union and their family members to move and reside freely within the territory of the Member States amending Regulation (EEC) No 1612/68 and repealing Directives 64/221/EEC, 68/360/ EEC, 72/194/EEC, 73/148/EEC, 75/34/EEC, 75/35/EEC, 90/364/EEC, 90/365/EEC and 93/96/EEC [2004] OJ L158/77.

49 Case C-209/03 Dany Bidar v London Borough of Ealing and Secretary of State for Education and Skills [2005] ECR I-2119.

50 Consolidated Version of the Treaty establishing the European Community [2002] OJ C325/33.

51 Case C-158/07 Jacqueline Förster v Hoofddirectie van de Informatie Beheer Groep [2008] ECR I-8507. 
another Member State may be entitled to a maintenance grant. The CJEU observed that it is legitimate for a Member State to grant assistance covering students' maintenance costs only to those students who have demonstrated a certain degree of integration into the society of that State, and that the existence of a certain degree of integration may be regarded as established by a finding that the student in question has resided in the host Member State for a certain length of time. ${ }^{52}$

The CJEU held that a condition of five years' uninterrupted residence was permissible for the purpose of guaranteeing that the applicant for the maintenance grant at issue is integrated into the society of the host Member State. It reached that conclusion by looking at Directive 2004/38 - although not applicable in time to the facts of the casewhich provides in article 24(2) that Member States are not obliged to grant maintenance assistance to students who have not acquired the right to permanent residence, which requires five years' continuous residence. ${ }^{53}$

Hence, the CJEU borrowed directly from the EU legislator to find a precise solution to the problem of eligibility for maintenance grants that it had determined in a different way in the earlier Bidar case, emphasising the degree to which the CJEU will defer to the legislator in its task of resolving cases. This has happened more recently in the case of social assistance benefits.

In Trojani, ${ }^{54}$ a case that also predated Directive 2004/38, the CJEU held that an EU citizen enjoyed a right of residence by direct application of article 18(1) EC. Once such a person had a resident permit he was entitled, pursuant to article $12 \mathrm{EC},{ }^{55}$ to be granted social assistance benefit, such as the minimex in Belgium. ${ }^{56}$

However, the analysis was different in the more recent case of Dano. ${ }^{57}$ The case concerned Ms Dano, a Romanian national who entered Germany in November 2010. For several years, Ms Dano and her son-who was born in Germany-had lived with Ms Dano's sister, who provided for them. Ms Dano did not enter Germany in order to look for work, nor was she actively seeking work in that country. In July 2011, Ms Dano was issued with a residence certificate of unlimited duration. The proceedings arose out of a request for benefits under the German Social Code by way of basic provision. Ms Dano's claim included subsistence benefits for herself, as well as social allowances and a contribution to accommodation and heating costs for her son. The case raised the question of whether EU law precludes nationals of other Member States from being refused entitlement to a special non-contributory cash benefit where the criteria adopted by the relevant host Member State, in this case Germany, excludes people who arrive

52 ibid paras 50-60.

53 ibid; art 16(1) Directive 2004/38.

54 Case C-456/02 Michel Trojani v Centre public d'aide sociale de Bruxelles (CPAS) [2004] ECR I-7573.

55 Art 12 Treaty of Lisbon: 'Within the scope of application of this Treaty, and without prejudice to any special provisions contained therein, any discrimination on grounds of nationality shall be prohibited.'

56 Case C-456/02 Trojani (n 54) para 46.

57 Case C-333/13 Elisabeta Dano and Florin Dano v Jobcenter Leipzig [2014] EU:C:2014:2358. 
solely in order to benefit from the social assistance scheme of that Member State, rather than seeking to integrate themselves into the labour market.

The CJEU began its analysis by pointing out that the rights of EU citizens to move and reside within the EU were, as per article 21(1) TFEU, subject to compliance with the limitations and conditions laid down in the Treaties and by measures adopted to give them effect. ${ }^{58}$ It therefore considered whether Ms Dano's residence met the conditions laid down in Directive 2004/38. It held that it did not. For a period of residence longer than three months in the case of someone who is not a worker, as was the case for Ms Dano, the resident needs to comply with article $7(1)(b)$ of the Directive, that is to say, to have sufficient resources for him- or herself and his or her family members not to become a burden on the social assistance system of the host Member State during their period of residence, and to have comprehensive sickness insurance cover in the host Member State. As the CJEU pointed out:

to accept that persons who do not have a right of residence under Directive 2004/38 may claim entitlement to social benefits under the same conditions as those applicable to nationals of the host member state would run counter to an objective of the directive, set out in recital 10 in its preamble, namely preventing Union citizens who are nationals of other member states from becoming an unreasonable burden on the social assistance system of the host member state. ${ }^{59}$

Such unequal treatment is a direct result of Directive 2004/38. It is founded on the link established by article 7 of the Directive between the need to have sufficient resources and the objective of not being a burden on the social assistance system of the host Member State. Seeing as Ms Dano and her son did not have sufficient resources, and so could not claim a right of residence in Germany under the Directive, they could not invoke the principle of non-discrimination laid down by article 24(1) of the Directive. The result was therefore different from that in Trojani, decided before Directive 2004/38 came into force.

I now turn to two recent cases regarding the entitlement to rights under EU employment legislation in the case of mothers who use surrogates for carrying and giving birth to their children. Surrogacy raises complex ethical and legal issues which are not easy to solve. In $C D v S T,{ }^{60}$ a reference from the UK, the CJEU was asked whether a woman who used the services of a surrogate for the birth of a child, but subsequently breastfed the baby, could benefit from the maternity provisions of Directive 92/85, ${ }^{61}$

58 ibid para 60.

59 ibid para 74.

60 Case C-167/12 CD v ST [2014] EU:C:2014:169. The CJEU reached the same conclusion in a subsequent case: Case C-363/12 Z v A Government department and Board of management of a community school [2014] EU:C:2014:159.

61 Council Directive 92/85/EEC of 19 October 1992 on the introduction of measures to encourage improvements in the safety and health at work of pregnant workers and workers who have recently given birth or are breastfeeding (tenth individual Directive within the meaning of Article 16(1) of Directive 89/391/EEC) [1992] OJ L348/1. 
which provides for certain measures in favour of breastfeeding mothers. CD was neither the biological nor the carrying mother of the child-she was the commissioning mother. The CJEU stated that the maternity leave provisions from which the female worker benefits under article 8 of the Directive are intended, first, to protect a woman's biological condition during and after pregnancy and, secondly, to protect the special relationship between a woman and her child over the period which follows pregnancy and childbirth, by preventing that relationship from being disturbed by the multiple burdens which would result from the simultaneous pursuit of employment. ${ }^{62}$ The CJEU inferred that the objective of the Directive is to protect the health of the mother of the child in the especially vulnerable situation arising from her pregnancy, and that the objective to ensure that the special relationship between a woman and her child is protected only concerns the period after 'pregnancy and childbirth.63 Consequently, seeing as CD had never been pregnant at any material time, she was not covered by the Directive despite breastfeeding the baby.

These cases are therefore also examples of where the CJEU is anxious not to usurp the role of the legislator. It is for the EU legislator to decide what, if any, protection should be given to commissioning mothers.

\section{The Charter of Fundamental Rights}

Article 6(1) of the TEU recognises the rights and freedoms set out in the Charter of Fundamental Rights as having the same legal value as the Treaties. The existence of human rights instruments always gives rise to the question of whether judges, when interpreting such instruments, might be said to override the democratic will of the people as expressed by the legislator. ${ }^{64}$ In this regard, I will refer to just one case decided recently by the CJEU.

In April 2014, the CJEU gave its ruling in the Digital Rights Ireland case. ${ }^{65}$ The CJEU found that the Data Retention Directive 2006/24 ${ }^{66}$ infringed article 7 of the Charter, concerning the respect for private life and article 8 on the protection of personal data. The Directive compelled internet service and telecommunications providers to collect and retain data from their subscribers for a period of between six months (minimum) and 24 months (maximum). This data included incoming and outgoing phone calls, IP addresses, and location data, but did not extend to the contents of the communications.

62 Case C-167/12 CD v ST (n 60) paras 34-35.

63 ibid para 36.

64 The dichotomy is not as great as is sometimes suggested since human rights instruments are themselves approved by the legislature. The problem arises because of the open-textured nature of a human rights instrument.

65 Joined Cases C-293/12 and C-594/12 Digital Rights Ireland and Seitlinger and Others [2014] EU:C:2014:238.

66 Council Directive 2006/24/EC of 15 March 2006 on the retention of data generated or processed in connection with the provision of publicly available electronic communications services or of public communications networks and amending Directive 2002/58/EC [2006] OJ L105/54. 
The CJEU found that the Directive's requirements made it possible for competent national authorities to access very precise information about the private lives of those whose data was retained and, as such, to interfere with the fundamental rights of respect for private life and protection of personal data. The key issue was whether this interference was justified as being proportionate. In assessing this question, the CJEU noted, in particular, that the Directive gave no objective criteria from which to determine the period of retention in order to ensure that it is limited to what is strictly necessary and lacked a number of procedural safeguards concerning access to the retained data. As such, the CJEU held that the Directive entailed a wide-ranging and particularly serious interference 'with the fundamental rights of practically the entire European population', which was not justified. ${ }^{67}$

The invalidation of the Directive in Digital Rights Ireland left a gap at the national level. In the UK, emergency primary and secondary legislation was adopted in order to fill this gap, as a lack of data retention powers would impact heavily on law enforcement. ${ }^{68}$ This new legislation reflects some of the concerns expressed by the CJEU in Digital Rights Ireland. ${ }^{69}$ The most significant change relates to the safeguards surrounding the retention of data. Prior to the judgment, the retention period in the UK was automatically set at 12 months. Under the new Regulations, retention of data may only occur in the UK if a retention notice is issued, which is not valid for a period of more than 12 months. Before the notice can be issued the Secretary of State must take into account a number of criteria, including the likely benefit of the notice, and the likely number of users it would affect. Furthermore, the retention notice must be kept under review. Thus, Digital Rights Ireland is a good example of how the CJEU and the legislature are able to ensure, within their respective fields, a high standard of human rights protection.

67 Joined Cases C-293/12 and C-594/12 Digital Rights Ireland (n 65) para 56.

68 The Data Retention (EC Directive) Regulations 2009, which was the UK statutory instrument giving effect to Directive 2006/24, no longer had a valid legal basis following Digital Rights Ireland (n 65). Those Regulations were replaced by primary legislation in the form of the Data Retention and Investigatory Powers Act 2014, together with implementing legislation in the form of the Data Retention Regulations 2014.

69 UK Government 'Data Retention and Investigatory Powers Bill: Government Note on the European Court of Justice Judgment' <https://www.gov.uk/government/uploads/system/uploads/attachment_data/ file/331106/DRIPgovernmentNoteECJjudgment.pdf $>$ accessed 31 August 2015. 